DOI: $10.24234 /$ wisdom.v18i2.528

Vadym ZUBOV,

Lyudmyla KRYVEGA

\title{
THE LIFE OF A MODERN PERSON: PHILOSOPHICAL REFLECTIONS
}

\begin{abstract}
The paper examines the main changes in the life and activity of modern person under the influence of the coronavirus pandemic. The aim of this article is to analyze the attributes of human life in a pandemic world. The object of the research - the life of a modern person in the context of the coronavirus pandemic. It is emphasized that a modern person is faced with the inconsistency of his life strategies with the logic and content of objective processes caused by the spread of the coronavirus and the emergence of severe restrictions on his freedoms, rights and directions of activity. Based on the dialectics of the objective and the subjective in social development, the authors distinguish and analyse the following consequences of the new global threat: the "impoverishment" of the human lifeworld, frozen social life, lack of contacts; more intense virtualisation of human life - digital is the new king; restricted face-to-face communication; the impossibility of travel and direct knowledge of cultural achievements of other countries.
\end{abstract}

Keywords: person, society, philosophy, coronavirus pandemic, social change, systemic crisis.

\section{Introduction}

The new format of society and human life in the context of the coronavirus pandemic necessitated the conceptualization of social changes. The person faced the inconsistency of his life strategies with the logic and content of objective processes caused by the spread of coronavirus and the emergence of severe restrictions on his freedoms, rights and directions of activity. The dialectics of the objective and the subjective allows explaining the interrelation of changes in the social processes and lifestyle of contemporary people. The pandemic attack of coronavirus on the social space has affected the existential aspects of the people's life making it turbulent, vulnerable and uncertain.

\section{Research Problem}

As regards the present state of the art in this sphere, one should state the following. The problem of studying the characteristics of the life of a modern person under the influence of the coronavirus pandemic is just beginning to attract the attention of scientists. But many European, American, Middle Eastern researchers as well as thinkers from other parts of the world reflected on the peculiarities of social life in the coronavirus dimension. They focused mainly on the following issues: - what a post-pandemic world will be and will the pandemic change the existing world order? (Mykhailychenko, 2020); - what route shall the world choose towards a different globalization? (Abdelnasser, 2020); - a universal declaration for a post-pandemic world? (Hegazy, 2020); - who will win and lose in the pandemic fight? (Said, 2020), etc. Such researchers as H. Kissinger (2020), V. Pastukhov (2020), A. Said (2020) and others explored various aspects of the problem in their works. Statistical and analytical materials, as well as electronic resources (UNWTO, World Travel and Tourism Council) served as the sources for comprehension and philosophical analysis of the peculiarities of human life in the pandemic world. One should note that 
the previous studies of the problem are descriptive, fragmented in their nature, and mainly focus on chosen sectors. Therefore, there is an urgent need to reflect on the social and philosophical peculiarities of human life in the pandemic world. The new "landscape" in which the society functions requires comprehensive philosophical research of the topic based on the research of the above-mentioned authors. The aim of the proposed article is to analyse the attributes of human life in a pandemic world. The object of the research - the life of a modern person in the context of the coronavirus pandemic.

\section{Research Methods}

Philosophical research involves the clarification of the essential characteristics of the object under study. The features of philosophical thinking are criticality, reflexivity and focus on understanding important problems of human existence. In this aspect, the use of a methodological complex was effective, the main principles of which are worldview pluralism, sociocultural determinism and interdependence of all spheres of human social life. The stated principles have found their expression in the dialectical, comparative, sociocultural approaches, which, on the basis of complementarity, form the basis of the methodological strategy for writing this article.

\section{The Result of the Study}

The existential crisis launches an active search for new meanings of human life in the "straitened" circumstances caused by the COVID-19 pandemic. Let us consider some of them in more detail.

The first and most important attribute of new format of life of the modern person is the "impoverishment" of the human lifeworld. The rapid coronavirus invasion of the world and a lack of knowledge about its nature and the ways it spreads has resulted in numerous restrictions on movements - leaving the place of living, region, co- untry, on certain types of activities, and a wide range of services (social, cultural, and healthcare). The human being has literally faced an existential threat due to the ban on elective surgery and the implementation of all medical guidelines but the coronavirus ones. Human life at the physiological level has become dependent on physical capabilities and a healthy lifestyle, the potential of which is difficult to maintain and develop for people with "sedentary behaviours". During the pandemic, the human being has ended up under a "house arrest" with an "escape" regulated by these or those quarantine guidelines or the full lockdown principles. The idea of "immunity passports" is being discussed for those who have been vaccinated and can, therefore, freely move around the country, work and do business. On the other hand, severe quarantine measures and regional restrictions seem to be the only effective methods to combat the coronavirus pandemic. Until the population has been vaccinated, the only relevant slogan for people is this, "stay at home and do not move out". Many countries of the world have closed their borders as well as shopping and entertainment centres, theatres, museums, art galleries, creative studios and associations, banned concert performances. In this way, they have deprived people of their "spiritual food" and have significantly reduced the emotional saturation and affective tone of their lives. The practices of medieval cities which dug moats and built unassailable fortresses have become actual again. One may talk of the globalisation crisis and the growth of national egoism. It should be noted that East Asia has done better on virus management and can serve as a role-model for other countries of the world. Trust and cooperation between the authorities and citizens are considered to be the reason for that.

Medical guidelines approved by the World Health Organisation and national medical communities replaced government regulation in contemporary society. Development of a vaccine against the coronavirus is seen as a decisive fac- 
tor of further social advancement. The so-called social coronavirus syndrome - regulated capitalism with certain totalitarian orientation and crisis of democracy - has appeared. The latter is caused by the large-scale restriction of human rights and freedoms, bans of particular forms and methods of implementing people's life strategies, manifestations of creative activity and possible modes of self-realisation. The coronavirus dimension of human existence repeats Plato's statement that the welfare of an individual must be subordinate to that of the whole society. The "impoverishment" of human life has resulted in the insufficient level of healthcare development, including the pharmaceutical industry; and the pandemic has only made this problem more acute and pointed to the lack of finance in the healthcare sector of some countries.

The second attribute and consequence of the global spread of coronavirus is the virtualisation of human life. A computer, smartphone and other electronic gadgets are becoming permanent partners, and the Internet is becoming a condition for its social existence: knowledge of what is happening and access to information of interest, communication and activities, including providing oneself with the means of livelihood, the implementation of creative activity and the consumption of cultural content. Modern man is faced with the restructuring of the entire social reproduction, and especially the economy, on digital rails, on the format of "digital mobilization". The most impressive growth of all commodities needed in the face of the coronavirus pandemic has been in the manufacture and sale of computers. A huge number of companies and millions of people were forced to rebuild directly from the wheels to an online mode of work, study, consulting and organization of their daily life. The pandemic has become an unwitting accelerator for the implementation of advanced IT solutions in all areas of public and private life. Modern man has received a "vaccination" by digitalization, which will determine the directions of his activity and forms of development in the future.
The crisis changes in the labour market have caused a modern person (and especially those who have lost their jobs) to search for new points of application of their labour potential. These are enterprises and sectors, the demand for products of which has increased sharply in the context of the pandemic. These include the production of protective equipment, cleaning services, grocery companies, online stores, and the provision of various types of online education. The winners were the companies that translated the search for clients on the Internet - from accountants to sewing curtains. They are likely to remain on the Web after all restrictions are lifted. In the postpandemic world, digital is the new king, as the space for human self-realisation has shrunk to the size of an open laptop or another gadget, and the second important ingredient in an isolated life is cooking and eating food. Because of the lockdown, people spend more time in the virtual social space: in the IT industry, online sales, express shipping, online banking as well as distance learning, upskilling, medical advice, access to works of art.

With the development of cloud solutions and the Internet of things, the digital space of contemporary society keeps track of almost every person on the planet, and this information is available to others, which helps make the lockdown period more pleasant.

Freelancing is on the rise, and people work online from home. Freelancer is an independent specialist (an outsourcer) who can fulfil orders for different clients in a very short time, promotes their services, and works online. The pandemic has contributed to the significant shift in online of such activities as journalism, law, programming, consulting, design in all its forms and a number of other services. However, in general, the pandemic has caused a rise in the unemployment level and growth of the social group named precariat. These are socially insecure workers who have no steady employment, switch between part-time and seasonal jobs, losing their expertise and demand for their skills and know- 
ledge. They are actually outsiders in the society as they have low social security and unstable income that is why they are socially aggressive, protest against different things including lockdown restrictions, for example, the weekend lockdown. Interestingly, the society has now divided into those who support the facemask regime and those who protest against it, as well as those who support the idea of the lockdown and the so-called COVID-dissidents.

The third attribute of the new pandemic dimension of life is restricted face-to-face communication. The pandemic has sharply reduced the communication list for everyone, and now, people mainly use social networks for individual or small group communication.

Family members, friends and colleagues have become just symbols, avatars or logins in our gadgets. Communication through modern IT platforms and applications provides only visual and sound information, while other senses smell, touch, and taste - are not involved in the interaction with the outside world during the pandemic, and thus communication becomes dull, tasteless, and impersonal, which causes emotional and sensuous resistance. People want to communicate face-to-face to experience a full range of feelings and emotions, which is impossible with indirect, computerised networking. Human communication activity usually aims at obtaining new knowledge, experiencing new sensations and situations, meeting new people or objects of contemplation, which is difficult during the coronavirus pandemic.

The isolation returns people to patriarchal values, and they have to spend a significant part of their time alone or with family members. Due to the lockdown or restriction of business areas, catering facilities (cafés, restaurants, and street food vendors), consumer services and entertainment establishments, the family has resumed nearly all functions of the above spheres, and many contemporary households, especially in cities, are not ready for that. Spending long and uneventful hours together, people tend to have disagree- ments, which damage their relations and cause destructive behaviour.

The idea of comparing family life during the lockdown to staying on a submarine in distress is quite accurate as spouses stop thinking rationally and care only about physical survival. It turns out that the frozen social life and the necessity to physically spend almost all the time together are not the best ways to improve relationships.

Every person needs a solitude zone, be it a small space and a short time. Even Arthur Schopenhauer stated in his book The Wisdom of Life that happiness can only be found in solitude. However, he thought of happiness as an illusion; and pursuing the goal of being happy people inevitably face frustration. Yet, people think that they should be lonely only for short periods in their life and that relationship, love and family are one of the most important values; still, not the only ones. "Because even the most beautiful house turns into prison if you cannot leave it. Moreover, even the most beloved person, who is locked with you, becomes a fellow inmate. In addition, eventually, the only thing you can think of together will be how to escape. If you are lucky. And you do not kill each other before that" (Boholepova, 2020).

The pandemic challenge has changed the forms of cognitive activity of modern man. $\mathrm{He}$ moved to a sofa, an armchair in front of the computer and during the quarantine appreciated the convenience of "watching sofa" and the opportunity: to have a huge selection of films, high-quality images and to determine the time and content according to his own taste and mood. It turned out to be much cheaper than going to the cinema with the whole family. The world's leading film studios are increasingly abandoning the race to make films at a cost comparable to the budget of a small country, and are focusing their attention on creating series that are very popular with humans in quarantine. A person compensates for the limitedness of his own life with events from the serial life and one-way communication with the characters of the serials. Catharsis from con- 
templation and experience of the problems of someone else's life softens the cruelty of restrictions and prohibitions of quarantine for a person, gives him emotional release.

The fourth attribute of the pandemic dimension of life is the impossibility of travel and direct knowledge of cultural achievements of other countries. Before the coronavirus pandemic, tourism was an integral part of human life. Tourism is a way to overcome the monotony and limitations of a person's daily life. Travel helped people break free from their everyday life, albeit interesting, but still monotonous. Through travel, people fulfil their desire to start a new cascade of events, to bring novelty into the routine of their being. They are chained to their place of living, property, work, environment and social roles. Moreover, tourism serves as a method of alleviating "the cultural discontent" (Z. Freud) and a type of activity allowing to diversify human life, to bring new colours and impressions into it and become one of "new nomads".

During the last decade, before the coronavirus pandemic, there has been growth dynamics among the people travelling around the world. The World Tourism Organisation uses the concept of "arrivals" in their statistics. Thus, in 2008 there were 922 million arrivals, in $2009-880$ million, in 2010 - 939 million, in $2011-980$ million, in 2012 - 1,035 million, in $2013-1,087$ million, in 2014 - 1,134 million, in $2015-1,184$ million, in 2016 - 1,239 million, in 2017 - 1,322 million, in 2018 - 1,400 million, in 2019 - 1,500 million. ${ }^{1}$ In other words, before the pandemic, one in every five people on Earth travelled. The thirst for new experiences, learning new cultural worlds and opening up new horizons in the preCOVID times was satisfied due to the welldeveloped global tourism infrastructure.

The pandemic affected tourism the most and, in fact, cooped people up. Tourism is one of the world's major economic sectors and supports

1 See the World Travel and Tourism Council (www.wttc.org). one in 10 jobs (330 million) in the world and accounts for $10.3 \%$ of global GDP. ${ }^{2}$ Currently, the resource which added purpose to human life has been reduced to a minimum and only to some extent is compensated by virtual travels where people can only contemplate, but cannot be subjects of real tourist activities.

\section{Conclusion}

Summing up the reflections on the changes in human life in the face of the new challenge - the coronavirus pandemic - one should emphasise the following. The key new circumstances people have to deal with are the "impoverishment" of the human lifeworld, frozen social life, lack of contacts; more intense virtualisation of human life - digital is the new king; restricted face-toface communication; the impossibility of travel and direct knowledge of cultural achievements of other countries. The life of a modern person has changed beyond recognition due to the coronavirus pandemic. He was faced with the problem of comprehending new meanings of life, developing new strategies for the implementation of his creative plans. The restriction of living space, rights and freedoms, the narrowing of real communication and the horizon of possibilities make a modern person look like the mythological hero Sisyphus. A. Camus in "The Myth of Sisyphus" interprets him as each of us, for a person's life is a constant unsuccessful rolling of a stone to the top of a mountain. And here it is important to understand the need to carry your cross (stone) and hope for success.

\section{References}

Abdelnasser, W. M. (2020, May 8). Towards a different globalization. Al-Ahram Weekly. Retrieved from: https://english.ahram.org.eg/NewsContent/4/0/36

2 See UNWTO (www.unwto.org). 
8695/Opinion/Towards-a-different-globalisation.aspx

Boholepova, A. (2020, November 7). Blyzost razryva. (The proximity of the gap, in Russian). Gazeta.ru Retrieved from www.gazeta.ru/comments/column/bog olepova/13350031.shtml

Hegazy, M. (2020, May 8). A universal declaration for a post-pandemic world. Al AhramWeekly,10. Retrieved from http://english.ahram.org.eg/NewsContentP/ 4/368700/Opinion/A-universal-declaration-for-a-postpandemic-world.aspx

Kissinger, H. A. (2020, April 3). The coronavirus pandemic will forever alter the world order. The Wall Street Journal. Retrieved from https://www.wsj.com/articles/the-coronavirus-pandemic-willforever-alter-the-world-order-11585953005

Mykhailychenko, D. (2020, March 30). Postko- ronavyrusnaia epokha? Pomenyaet li pandemiya miroustroistvo (Post-coronavirus era? Will the pandemic change the world order, in Russian). Regnum. Retrieved from https://regnum.ru/news/society/2898800.html

Pastukhov, V. (2020, May 23). Postkoronavirusnyi sotsial'nyi sindrom: reguliruemyi kapitalizm i krizis demokratii (Post-coronavirus social syndrome: Regulated capitalism and the crisis of democracy, in Russian). Radio "Ekho Moskvy" (Radio "Echo of Moscow”, in Russian). Retrieved from https://echo.msk.ru/blog/pastuhov_v/2647905-echo

Said, A.-M. (2020, May 7). In a troubled world. Al-Ahram Weekly, 8. Retrieved from http://english.ahram.org.eg/NewsConte ntP/4/368690/Opinion/In-a-troubledworld.aspx 